\title{
Spawanie to nie wszystko Zabezpieczenie antykorozyjne spawanych konstrukcji stalowych - kontrola i badania
}

\author{
The welding it is not all \\ Corrosion protection of welding steel contruction \\ - inspection and testing
}

\begin{abstract}
Streszczenie
W artykule wskazano na konieczność właściwego traktowania elementu trwałości konstrukcji spawanych, jakim jest zabezpieczenie antykorozyjne. Wskazano na dokumenty zawierające wymagania w zakresie ochrony antykorozyjnej konstrukcji.

Zwrócono uwagę na konieczność przestrzegania tychże wymagań na wszystkich etapach wytwarzania konstrukcji począwszy od projektowania, a kończąc na nałożeniu zabezpieczenia antykorozyjnego. Omówiono procesy projektowania, przygotowania powierzchni, nakładania powłok antykorozyjnych oraz kontroli procesu na poszczególnych etapach jej wykonania. Artykuł w szczególności zwraca uwagę na bezwzględną konieczność spełnienia wymagań w zakresie kwalifikacji i kompetencji personelu antykorozji.
\end{abstract}

Słowa kluczowe: zabezpieczenie antykorozyjne; konstrukcje stalowe; korozja; specyfikacja elementu

\begin{abstract}
In the paper present necessity of correct treat the welding construction with respect to durability given by corrosion protection. Its present the documents contain requirements in scope of corrosion protection of construction.

Its note for necessity to follow mentioned rules in each stage of manufacture steel construction start from design to finish with application of corrosion protection. Description of design process, surface preparation, application and process control in particular stages is described. The paper especially pay attention for strictly request to fulfil the requirements in scope of qualification and competence corrosion protection personnel.
\end{abstract}

Keywords: corrosion protection; steel constructions; corrosion; component specification

\section{Wstęp}

Zaprojektowanie i wykonanie konstrukcji stalowej zdolnej do użytkowania w środowisku o określonej kategorii korozyjności, przez określony czas to zadanie złożone i niełatwe. Oprócz wyliczeń wytrzymałościowych należy w projekcie uwzględnić wymagania dotyczące jej wykonania, wraz z ograniczeniami wynikającymi z procesu spawania. Dla zapewnienia oczekiwanej trwałości konstrukcji w procesach projektowania i wykonania musimy jeszcze uwzględnić bardzo ważny element, a mianowicie zabezpieczenie antykorozyjne. By spełniło ono swoją funkcję musi być spełnionych kilka warunków. Już na etapie założeń projektowych powinien zostać dokonany wybór rodzaju zabezpieczenia antykorozyjnego. W procesie projektowania należy uwzględnić specyficzne wymagania, jakie są niezbędne, by możliwe było prawidłowe jego nałożenie. Wyzwaniem jest również sam proces nakładania powłok antykorozyjnych począwszy od zapewnienia właściwych warunków środowiskowych, poprzez monitorowanie właściwego przebiegu nakładania powłok, a na badaniach wykonanych powłok kończąc. Podobnie jak proces spawania tak proces antykorozji zaliczany jest do procesów specjalnych w całym cyklu wytwarzania konstrukcji.

\section{Korozja, a trwałość konstrukcji stalowych \\ Przez pojęcie „korozja” rozumiemy fizykochemiczne oddziaływanie między środowiskiem i metalem, w którego}

Mgr inż. Jerzy Kozłowski - SLV-GSI Polska Sp. z o.o.; mgr inż. Jakub Kozłowski - Politechnika Częstochowska.

Autor korespondencyjny/Corresponding author: kuba.kozlowski@o2.pl 
wyniku powstają zmiany we właściwościach metalu, które mogą prowadzić do znaczącego pogorszenia funkcji metalu, środowiska lub układu technicznego, którego są częściami [1]. Procesy korozyjne zachodzą wówczas, gdy środowisko, w którym znajduje się metal zawiera czynniki korozyjne: chemiczne (kwasy, zasady, chlorki, substancje utleniające); mechaniczne (naprężenia, przepływ medium, prądy błądzące), biologiczne (mikroorganizmy), itp.

Korozja zachodzi zarówno w środowiskach naturalnych takich jak atmosfera, woda, ziemia, jak i w środowiskach związanych z działalnością człowieka (roztwory powstające w związku z działalnością przemysłową i bytową).

Najważniejszym skutkiem korozji jest ubytek masy metalu poprzez przekształcenie się jej w produkty korozji. Istotnym staje się utrata użyteczności konstrukcji ze względu na obniżenie jej wytrzymałości. Efekt ten może wystąpić już przy niewielkich, w stosunku do całej konstrukcji, ubytkach korozyjnych np. w przypadku korozji wżerowej lub korozji naprężeniowej. Ponadto korozja powodując znaczne uszkodzenia konstrukcji, ma ogromne skutki ekologiczne oraz stanowi zagrożenie dla gospodarki i środowiska.

Z powyższego wynika, że korozja to proces znacznie obniżający trwałość konstrukcji.

Z drugiej zaś strony - przewidywana trwałość jest jedną z zasadniczych danych wejściowych do projektowania konstrukcji. Przy czym "trwałość" - należy w tym wypadku rozumieć, jako przydatność konstrukcji dla określonego lub długiego czasu użytkowania, bez utraty właściwości użytkowych lub jej osłabienia przy założonych w projekcie warunkach eksploatacji. Trwałość konstrukcji zależy od jej zastosowania, warunków ekspozycji i wszystkich, zastosowanych środków ochrony przed korozją (np. powłoki malarskie, cynkownie ogniowe, powłoki nanoszone poprzez natryskiwanie cieplnie, powłoki duplex).

Ze względu na to, że nie ma bezpośredniej metody badania trwałości, ocenia się ją pośrednio, sprawdzając wymagania dotyczące zabezpieczenia powierzchni elementu z warunkami jego ekspozycji.

Ważność procesu zabezpieczenia antykorozyjnego powinna wymuszać na wykonawcach, by był on prowadzony we właściwych warunkach i nadzorowany przez kompetentny personel.

\section{Wymagania dla zabezpieczenia antykorozyjnego konstrukcji}

Jak przedstawiono w powyższym akapicie, zabezpieczenie antykorozyjne konstrukcji stalowych to niezmiernie ważny element ich trwałości i niezawodnej eksploatacji.

Wymagania dla zabezpieczenia antykorozyjnego konstrukcji znajdziemy między innymi:

- dla konstrukcji stalowych - w serii norm EN ISO 12944[2]. Normy zawierają wymagania odnośnie klasyfikacji środowisk korozyjnych, projektowania, przygotowania powierzchni, systemów ochronnych, laboratoryjnych metod badań, wykonywania i nadzoru prac malarskich oraz opracowania dokumentacji.

- dla konstrukcji budowlanych - w PN-EN 1090[3]. Wykonanie konstrukcji stalowych i aluminiowych w jej pierwszej części „Zasady oceny zgodności elementów konstrukcyjnych". W punkcie 4 dotyczącym wymagań dla elementów konstrukcji, odnosząc się do trwałości norma nakazuje, by wszystkie wymagania dotyczące zabezpieczenia przed korozją określone zostały w specyfikacji elementu. W części 2 normy dotyczącej wyma- gań technicznych, w rozdziale 10 określono wymagania dotyczące przygotowania powierzchni elementów do nakładania powłok malarskich lub innych, po wytworzeniu elementu konstrukcji. Przywołana jest również konieczność uwzględnienia w specyfikacji wyrobu wymogów dotyczących zastosowania konkretnego systemu powłok antykorozyjnych.

- dla konstrukcji offshore - w normie NORSOK M501[4]. Norma określa wymagania dla wszystkich etapów procesu antykorozji począwszy od przygotowania powierzchni, a na kontroli i badaniach kończąc;

- dla konstrukcji mostowych - w "Zaleceniach do wykonywania i odbioru antykorozyjnych zabezpieczeń konstrukcji stalowych drogowych obiektów mostowych" [5];

- dla konstrukcji napowietrznych linii elektroenergetycznych - w wytycznych firm np. Tauron [6], PSE Operator [7].

Wytyczne dla procesu antykorozji powinny obejmować wszystkie jej etapy począwszy od projektowania konstrukcji, poprzez dobór najbardziej odpowiedniego systemu antykorozyjnego, przygotowanie powierzchni, nakładanie powłok, kontrole i badania na każdym etapie procesu, a na wymaganiach dotyczących przeglądów i renowacji systemu powłokowego kończąc. Ze względu na swą ważność dla eksploatacji konstrukcji, powinny być opracowywane przez osoby posiadające odpowiednie kwalifikacje i doświadczenie.

\section{Projektowanie konstrukcji, a zábezpieczenie antykorozyjne}

Skuteczne zabezpieczenie antykorozyjne konstrukcji rozpoczyna się już na etapie projektowania konstrukcji. Projekt powinien zapewniać, że konstrukcja jest odpowiednia dla wyznaczonej jej funkcji, ma wymaganą stabilność, wytrzymałość i trwałość oraz akceptowalny koszt wytworzenia i zadowalający pod względem estetycznym wygląd. Konstrukcja powinna być zaprojektowana tak by możliwe było właściwe przygotowanie powierzchni, nałożenie powłok, nadzór nad eksploatacją i renowację po założonym czasie użytkowania. Na etapie projektowania należy, na podstawie zakładanego okresu trwałości konstrukcji i kategorii korozyjności środowiska w miejscu jej zainstalowania, określić:

- rodzaj systemu antykorozyjnego (np. powłoki malarskie, cynkowanie ogniowe, natryskiwanie cieplne, system duplex);

- parametry systemu (liczba warstw, grubość poszczególnych warstw i grubość całkowita, wymagania jakościowe powłoki);

- wszystkie inne niezbędne informacje, by zabezpieczenie to było możliwe do wykonania.

Koniecznym jest również określenie dopuszczalnego stopnia skorodowania materiałów użytych do budowy konstrukcji, rodzaju i parametrów dla czyszczenia powierzchni przed nałożeniem powłok, metod nakładania powłok, miejsca nakładania (wytwórnia, budowa), wymagań jakościowych dla wykonanego zabezpieczenia.

We właściwym, pod względem antykorozyjnym, zaprojektowaniu konstrukcji pomocne są wymagania przedstawione w normach EN ISO 12944-3[2], EN ISO 14713[8].

EN ISO 12944-3 zawiera zasady projektowania konstrukcji pokrywanych powłokami malarskimi w stosunku do $\mathrm{np}$.:

- dostępności dla celów nakładania, kontroli i renowacji ochronnego systemu malarskiego;

- postępowania z wąskimi szczelinami;

- unikania ukształtowań powierzchni sprzyjających gromadzeniu się wody; 
- niedokładności spoin (pęcherzy, kraterów rozprysków);

- elementów skrzynkowych i elementów z pustymi przestrzeniami;

- uwzględnienia potrzeb w zakresie transportu i montażu. W swych załącznikach podaje prawidłowe rozwiązania projektowe.

Wymagania dla powłok cynkowych i aluminiowych uzyskiwanych za pomocą cynkowania ogniowego i natryskiwania cieplnego zawiera EN ISO 14713[8]. Oprócz wymagań sugeruje rozwiązania projektowe, by nałożone powłoki były skuteczne w zakresie ochrony antykorozyjnej. Zaleca np.:

- konieczność unikania zamkniętych szczelnie przestrzeni ze względu na możliwość wybuchu podczas cynkowania;

- wykonywanie otworów technologicznych dla ułatwienia dopływu i odpływu stopionego cynku;

- wykonywanie otworów odpowietrzających dla zapobieżenia powstawaniu tzw. kieszeni powietrznych, a w ich konsekwencji obszarów niedocynkowanych;

- dążenie do symetryczności konstrukcji i unikanie dużych różnic w grubościach ścian lub przekrojach wyrobu dla minimalizacji naprężeń wewnętrznych będących przyczyną odkształceń i/lub pęknięć konstrukcji podczas cynkowania;

- wskazuje potrzebę przedyskutowania procesu spawania również ze specjalistami od cynkowania zanurzeniowego w celu zminimalizowania występujących naprężeń.

Należy pamiętać, że temperatura kąpieli cynkowniczej, w której zanurzamy konstrukcję to ok. $450^{\circ} \mathrm{C}$.

Koniecznym zatem jest, by projektanci konstrukcji mieli odpowiednią wiedzę również w zakresie antykorozji lub mieli możliwość konsultacji z osobami kompetentnymi w tym zakresie. Opracowany projekt powinien zostać również zweryfikowany przez kompetentnego i doświadczonego inspektora ochrony antykorozyjnej. Kompetencje i doświadczenie inspektora powinny być określone w wymaganiach dla projektu.

Tylko taki tryb postępowania może zapewnić skuteczną ochronę antykorozyjną konstrukcji.

\section{Przygotowanie powierzchni do nakładania powłok antykorozyjnych}

\section{Wymagania}

Przygotowanie powierzchni przed nakładaniem powłok antykorozyjnych to jeden z zasadniczych etapów mających wpływ na późniejszą jakość powłoki.

Wybór stopnia przygotowania uzależniony jest od wymagań systemu powłokowego, korozyjności środowiska, w którym konstrukcja będzie użytkowana, możliwości wykonania danej metody czyszczenia w zestawieniu ze stopniem przygotowania.

Proces przygotowania powinien być, co do wymagań, zdefiniowany poprzez przywołanie klas i stopni, zgodnie z wymaganiami zawartymi w odpowiednich normach przedmiotowych.

Między innymi określić należy:

- dopuszczalny stopień skorodowania materiałów przed ich czyszczeniem (A, B, C, D), oraz stopnie czystości powierzchni po czyszczeniu (np. Sa1, Sa2, Sa $2 \frac{1}{2}$, Sa3) - patrz EN ISO 8501-1[9];

- stopień przygotowania spoin, krawędzi i innych obszarów z wadami powierzchni (P1, P2, P3) - patrz EN ISO 8501-3 [10];

- parametry profilu powierzchni uzyskanego po czyszczeniu strumieniowo-ściernym (drobnoziarnisty, pośredni, gruboziarnisty) - patrz norma EN ISO 8503-2[11];
- stopnie pozostałej ilości kurzu (stopnie od 1 do 5) - patrz EN ISO 8502-3[12];

- dopuszczalną ilość pozostałych soli rozpuszczalnych w wodzie, pozostających na powierzchni - patrz EN ISO 8502-6;-9[12].

\section{Kontrola i metody badań}

Do stwierdzenia czy rzeczywisty stan przygotowanej powierzchni odpowiada wymaganiom postawionym w specyfikacji dla zabezpieczenia antykorozyjnego i/lub kartach technicznych materiałów malarskich, należy przeprowadzić odpowiednie badania.

Badania powinny być przeprowadzone przez kompetentny i doświadczony personel. Badania przygotowania powierzchni powinien również wykonać inspektor antykorozji działający np. w imieniu inwestora. W trakcie badań należy określić spełnienie wymagań w zakresie:

- wymaganego stopnia skorodowania powierzchni przed operacją czyszczenia, na podstawie wzorców fotograficznych zawartych w EN ISO 8501-1[9]. Norma przewiduje cztery stopnie skorodowania - A, B, C, D. Przy czym stopień $A$ to powierzchnia stalowa $w$ znacznym stopniu pokryta mocno przylegającą zendrą, stopień D to powierzchnia stalowa, na której zendra całkowicie przekorodowała i gołym okiem widoczne są wżery korozyjne w podłożu;

- wymaganego stopnia czystości powierzchni po czyszczeniu, określanego również na podstawie wzorców fotograficznych. W EN ISO 8501-1[9] znajdują się wzorce dla stopni po obróbce strumieniowo-ściernej (Sa1,Sa2, $\mathrm{Sa} 2 \frac{1}{2}, \mathrm{Sa}$ ), po czyszczeniu narzędziem ręcznym (St2 i St3), czyszczeniu płomieniowym (FI). Przy czym stopień Sa1 - to obróbka zgrubna, a stopień Sa3 to powierzchnia o jednolitej barwie metalicznej;

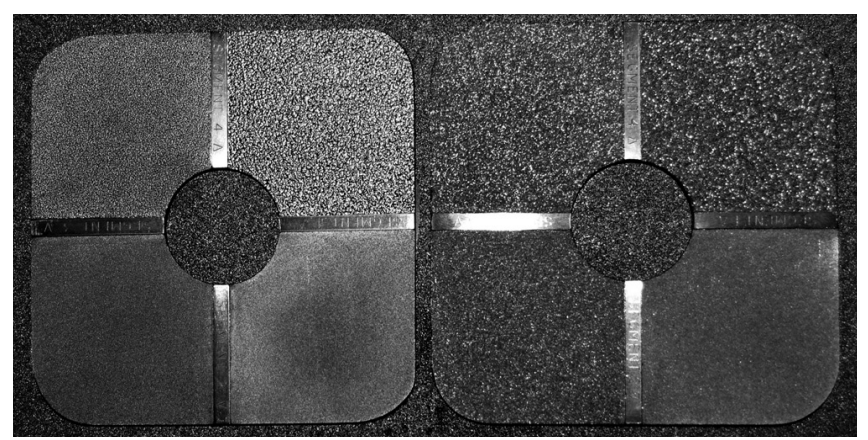

Rys. 1. Wzorce G i S

Fig. 1. Comparators $\mathrm{G}$ and $\mathrm{S}$

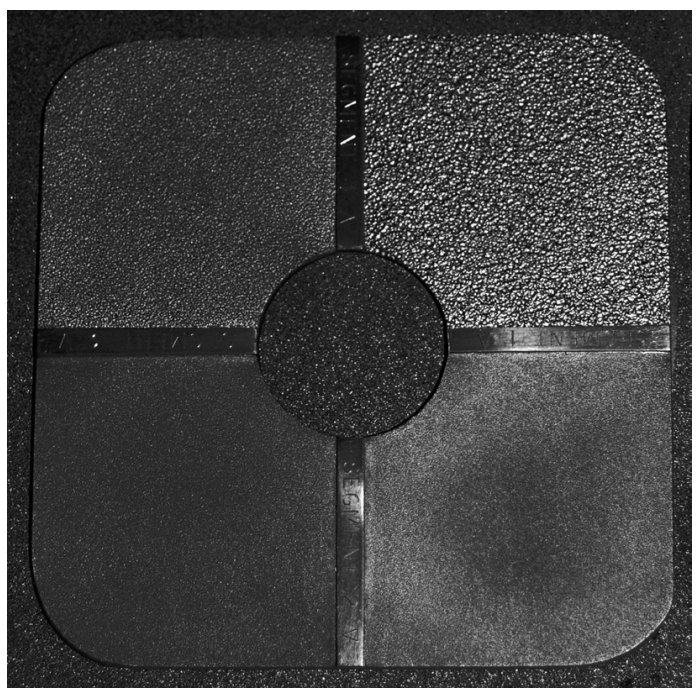

Rys. 2. Zastosowanie wzorca

Fig. 2. Comparator procedure 
Tablica I. Przykłady wad w zależności od wymaganego stopnia przygotowania powierzchni Table I. Examples of defects according to the degree of surface preparation

\begin{tabular}{|c|c|c|c|c|}
\hline \multicolumn{2}{|c|}{ Rodzaj wady } & \multicolumn{3}{|c|}{ Stopnie przygotowania } \\
\hline Opis & Ilustracja & P1 & P2 & P3 \\
\hline $\begin{array}{l}1.1 \\
\text { Rozprysk } \\
\text { spawalniczy }\end{array}$ & 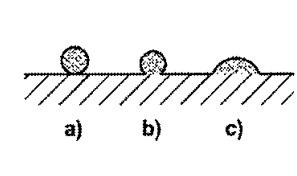 & $\begin{array}{l}\text { Na powierzchni nie } \\
\text { powinno być żadne- } \\
\text { go luźnego rozpry- } \\
\text { sku spawalniczego a }\end{array}$ & $\begin{array}{l}\text { Na powierzchni nie powinno być } \\
\text { żadnego luźnego i słabo przyle- } \\
\text { gają- cego rozprysku (patrz a i b). } \\
\text { Może pozostać rozprysk jak w c }\end{array}$ & $\begin{array}{l}\text { Na powierzchni nie po- } \\
\text { winno być żadnego roz- } \\
\text { prysku spawalniczego }\end{array}$ \\
\hline $\begin{array}{l}1.2 \\
\text { Łuska } \\
\text { /profil spoiny }\end{array}$ & & Brak przygotowania & $\begin{array}{l}\text { Powierzchnię należy obrobić } \\
\text { (np. metodą szlifowania), } \\
\text { aby usunąć wszystkie nieregu- } \\
\text { larne i ostre krawędziowe profile }\end{array}$ & $\begin{array}{l}\text { Powierzchnię całkowicie } \\
\text { obrobić tj. wygładzić }\end{array}$ \\
\hline $\begin{array}{l}2.3 \\
\text { Krawędzie } \\
\text { cięte } \\
\text { na gorąco }\end{array}$ & & $\begin{array}{l}\text { Na powierzchni nie } \\
\text { powinno być żużla i } \\
\text { luźnej zgorzeliny }\end{array}$ & $\begin{array}{l}\text { Żadna z części krawędzi nie po- } \\
\text { winna mieć nieregularnego profilu }\end{array}$ & $\begin{array}{l}\text { Powierzchnię cięcia na- } \\
\text { leży usunąc, a krawędzie } \\
\text { zaokrąglić do promienia } \\
\text { nie mniejszego niż } 2 \mathrm{~mm}\end{array}$ \\
\hline
\end{tabular}

- wymaganego stopnia przygotowania spoin, krawędzi i innych obszarów z wadami powierzchni. Oceny dokonuje się na podstawie oględzin i porównania z wymaganiami zawartymi w EN ISO 8501-3[10] (przykłady tabl. I);

- uzyskania wymaganego profilu powierzchni. Profil powierzchni ocenia się za pomocą wzorców porównawczych. W zależności od użytego ścierniwa do oceny należy zastosować: wzorzec G (grit) - dla ścierniwa ostrokątnego, wzorzec S (shot) dla ścierniwa kulistego (rys. 1 i 2).

Umieszczamy odpowiedni wzorzec, G lub S (rys. 1), na badanej powierzchni (rys. 2) i kolejno porównujemy ją wzrokowo (w razie potrzeby z użyciem szkła powiększającego) z segmentami wzorca. Określenie profilu powierzchni można również zrealizować za pomocą urządzeń do pomiaru chropowatości powierzchni (przykład rys. 3).
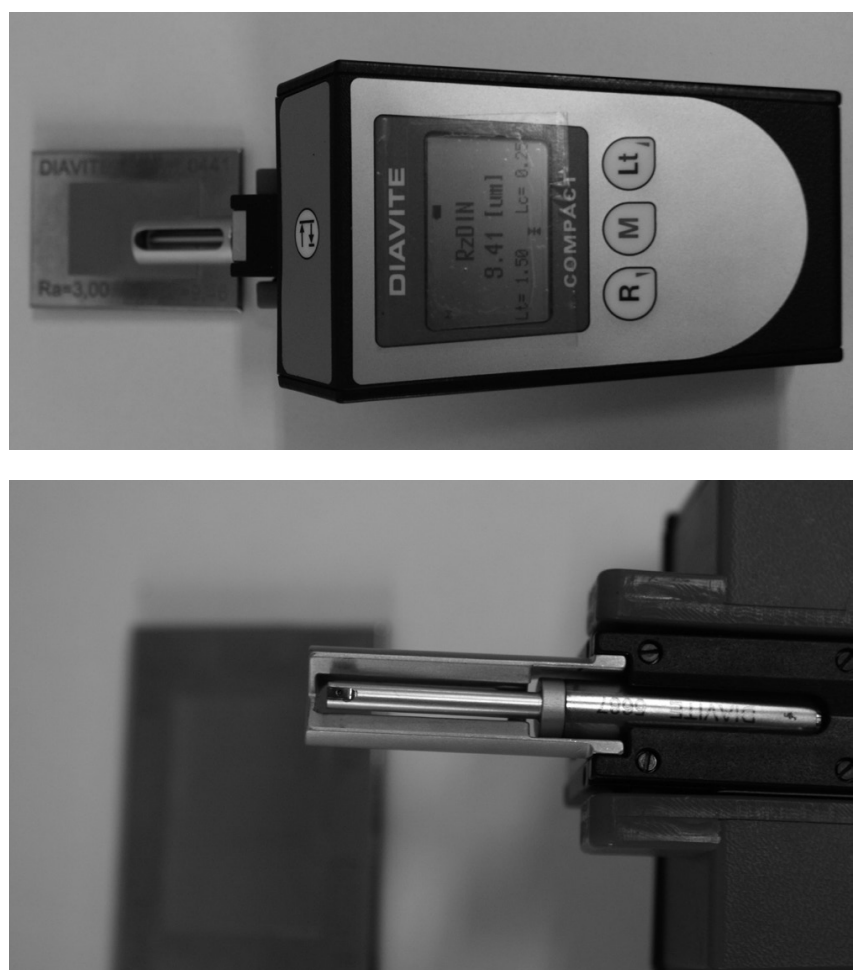

Rys. 3. Chropowatościomierz

Fig. 3. Surface roughness tester
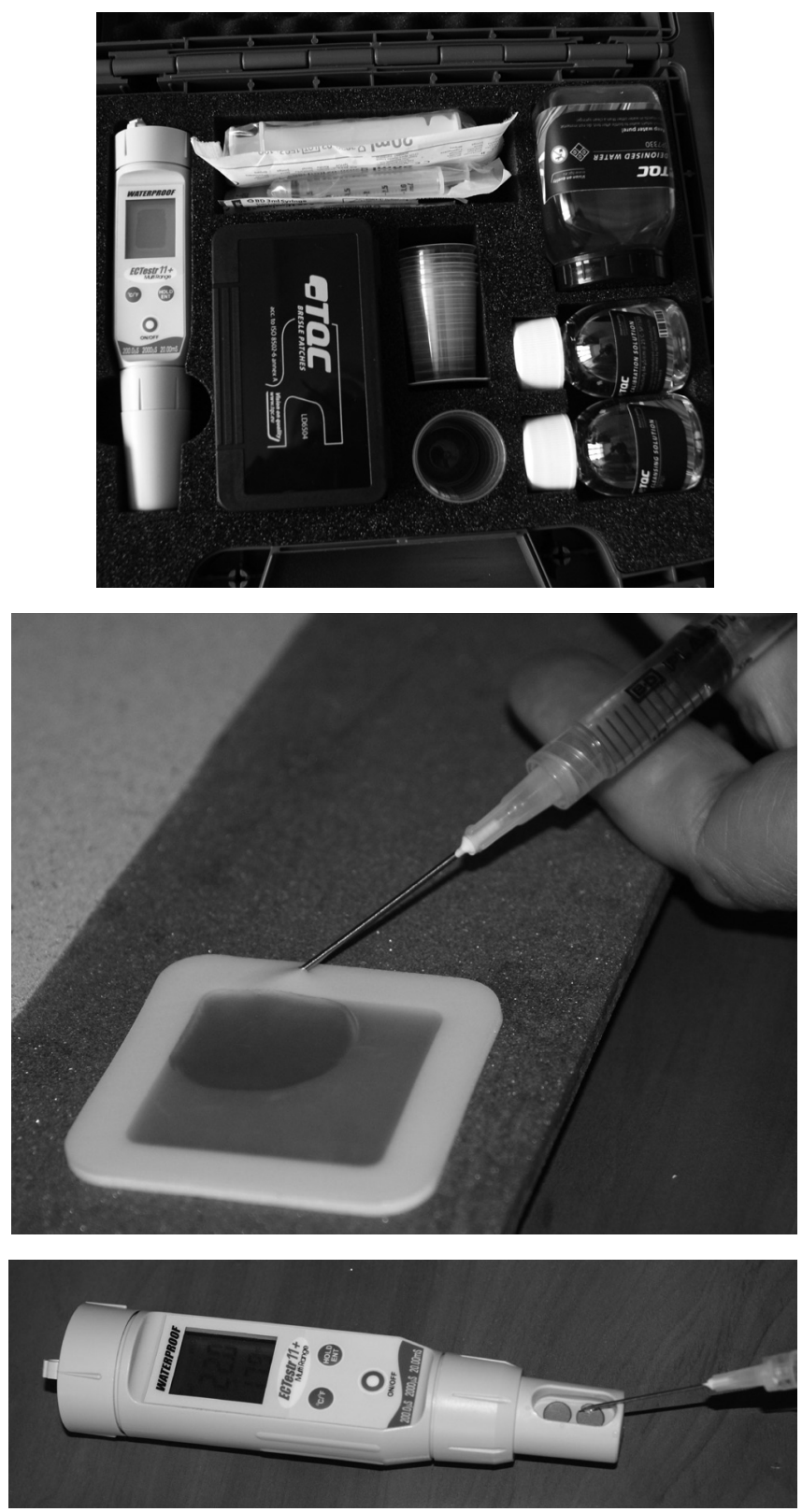

Rys. 4. Badanie metodą Bresle'a

Fig. 4. Test on Bresle'a 
- dopuszczalnego stopnia pozostałej ilości kurzu. Badanie to można przeprowadzić według postanowień EN ISO 8502-3[12] za pomocą taśmy samoprzylepnej. Odcinek przeźroczystej taśmy przyklejamy na badanej powierzchni, dociskamy kciukiem lub specjalnym wałkiem obciążonym sprężyną. Po oderwaniu taśmy przyklejamy ją na płytę obrazową i porównując wzrokowo powierzchnię taśmy z wzorcami zamieszczonymi w ww. normie. Na tej podstawie ocenimy stopień ilości kurzu (od 1 do 5) oraz klasę wielkości cząstek kurzu (od 0 do 5 przy czym " 0 " to cząstki niewidoczne przy powiększeniu 10x, "5" - to cząstki o średnicy ponad 2,5 mm).

- dopuszczalnego poziomu pozostałej ilości soli rozpuszczalnych w wodzie. Badanie to można przeprowadzić np. metodą Bresle'a, w oparciu o wymagania EN ISO 85026 i-9[12] (patrz rys. 4). Na badanej powierzchni umieszczamy samoprzylepną celkę. Do jej komory wstrzykujemy rozpuszczalnik (woda destylowana), a następnie ją odciągamy. Czynność tę powtarzamy, wg EN ISO 8502-9 dziesięć razy, po czym dokonujemy pomiaru przewodnictwa rozpuszczalnika za pomocą konduktometru. Wymagany poziom powinien być określony w specyfikacji zabezpieczenia.

Przedstawione metody to przykłady badań jakie są możliwe do zastosowania przy ocenie przygotowania powierzchni przed nałożeniem powłok antykorozyjnych. By dokonać najbardziej racjonalnego wyboru metody wymagana jest wiedza i doświadczenie osób prowadzących badania i kontrole.

\section{Nakładanie i kontrola powłok}

Prace związane z nakładaniem powłok malarskich muszą być nadzorowane na wszystkich etapach. Za nadzór odpowiedzialny jest wykonawca powłok. Oczywiście celowym również jest nadzór prowadzony ze strony zleceniodawcy. Jeśli przewidziane do zastosowania wyroby lakierowe nie są znane wykonawcy, powinien on skonsultować się z ich producentem.

Zakres nadzoru powinien zależeć od rodzaju i znaczenia konstrukcji, rodzaju nakładanej powłoki i przewidzianego okresu trwałości konstrukcji.

Podczas wykonywania prac powinno się zadbać o to, by na prace nie miały wpływu czynniki zewnętrzne mogące wpłynąć na pogorszenie właściwości powłok. Najniższa i najwyższa dopuszczana temperatura oraz wilgotność względna powietrza przy nakładaniu powłok powinna spełniać wymagania zawarte w kartach technicznych farb. Ponadto temperatura otoczenia i elementu nie powinna być niższa niż $3^{\circ} \mathrm{C}$ powyżej temperatury punktu rosy, a wilgotność względna nie powinna przekraczać $80 \%$. Parametry te należy kontrolować i dokumentować w trakcie całego procesu. Nadzorowi podlega również sposób przygotowania materiałów malarskich oraz technika ich nakładania. Należy przestrzegać zasad np. wykonywania tzw. wyprawek malarskich, wymalowań wzdłuż krawędzi pasów ok. $25 \mathrm{~mm}$ (patrz np. wymagania EN 1090-2 F.6.1 [3]), regularnego pomiaru grubości „na mokro” w celu uzyskania pewności uzyskania grubości nominalnej, przestrzeganie przerw miedzy nakładaniem poszczególnych warstw.

Wykonane, gotowe powłoki antykorozyjne podlegają kontroli i badaniom, których zakres oraz sposób prowadzenia powinien być określony w specyfikacji wyrobu.

Najczęściej stosowane metody kontroli powłok to: ocena wzrokowa pod względem jednolitości barwy i obecności wad (zmarszczenie, kraterowanie, spękanie, zacieki, pęcherze powietrza itp.); pomiar grubości powłoki (patrz EN ISO
2808[13], EN ISO 19840[14]), pomiar przyczepności powłoki (patrz EN ISO 2409[15] oraz EN ISO 4624[16]).

W przypadku wykrycia niezgodności koniecznym jest wdrożenie działań naprawczych.

Jak wynika z przywołanych elementów procesu nakładania oraz kontroli wykonanych powłok, jest to kolejny duży obszar wiedzy, jaki musi posiadać personel wykonujący i nadzorujący prace antykorozyjne.

\section{Personel i jego kwalifikacje}

EN ISO 12944-7[2] już w punkcie dotyczącym warunków wstępnych dla wykonania prac malarskich wymaga by "firmy zawierające umowy na nakładanie ochronnych systemów malarskich na konstrukcje stalowe, i ich personel, powinny być zdolne do wykonania tych prac w sposób prawidłowy i bezpieczny. Prace wymagające szczególnej staranności powinny być wykonywane jedynie przez personel mający kwalifikacje potwierdzone przez upoważnioną instytucję, pod warunkiem, że strony nie uzgodniły inaczej".

Podobne zapisy dotyczące kompetencji personelu mającego wpływ, na jakość wyrobu znajdziemy w EN ISO 9001[17] czy EN 1090-1[3]. Personel zaangażowany w nadzór nad wykonaniem powłok, kontrolę prawidłowości wykonanych powłok powinien mieć odpowiednie kwalifıkacje i powinien być szkolony w zakresie prowadzonych prac.

Wiedza personelu powinna obejmować zakres między innymi: przygotowania powierzchni do nałożenia powłok; rodzajów materiałów powłokowych oraz wymagań dla ich zastosowania, przechowywania i przygotowania materiałów powłokowych do użycia; właściwych warunków środowiskowych dla nakładania powłok; kontroli procesu w czasie nakładania powłok; kontroli i badań wykonanych powłok; wad występujących w powłokach i ich przyczyn; prowadzenia dokumentacji związanej z dokumentowaniem warunków i przebiegu procesu jak również kontroli i badań wykonanych powłok.

By takowa wiedzę zdobyć konieczne jest kierowanie personelu na dobre merytorycznie szkolenia.

Niestety w wielu organizacjach kształcenie personelu pozostaje na poziomie krótkiego, kilkugodzinnego szkolenia, przeprowadzonego przez przedstawiciela wytwórcy farb skupiające się raczej na reklamie własnych wyrobów lakierniczych, niż na przekazywaniu wiedzy z antykorozji. Szkolenia takie dają poza wystawionym świadectwem, tylko złudzenie pełnego zapoznania się z procesem.

$\mathrm{Na}$ runku polskim mamy niestety niewiele szkoleń dających szeroką wiedzę z dziedziny antykorozji. Należy tu wymienić 3-stopniowy kurs „Projektowanie i nadzór nad wykonywaniem zabezpieczeń antykorozyjnych na konstrukcjach stalowych" prowadzony przez Instytut Badawczy Dróg i Mostów. Z uznanych na rynku międzynarodowym kursów należy wymienić norweskie FROSIO oraz amerykańskie NACE. W wielu wypadkach, np. wymagania IMO (Międzynarodowa Organizacja Morska), to tylko inspektorzy z certyfikatami FROSIO lub NACE mogą nadzorować prace antykorozyjne zbiorników balastowych statków, konstrukcji offshorowych itp. Trudnościami w dostępności tych kursów jest niestety wysoka cena oraz język angielski, w którym prowadzone są wykłady i egzamin. Część z tych przeszkód w ostatnim czasie została na polskim rynku pokonana. W lutym br. odbył się pierwszy w Polsce kurs FROSIO prowadzony w języku polskim. Również w języku polskim prowadzony był egzamin. Organizatorem kursu jest SLV Duisburg (jednostka dopuszczona przez FROSIO do prowadzenia szkoleń) przy współudziale z SLV-GSI Polska, a kolejne edycje szkolenia mają odbywać się w sposób cykliczny. 


\section{Podsumowanie}

Aby zapewnić prawidłową pracę konstrukcji nie wystarczy jej tylko właściwie pod względem wytrzymałościowym zaprojektować i wykonać, najczęściej z wykorzystaniem procesów spawalniczych. Koniecznym jest również uwzględnienie wymagań wynikających z warunków dla wykonania skutecznego zabezpieczenia antykorozyjnego.

Ze względu na to, że powłoki antykorozyjne mają bezpośrednie przełożenie na trwałość konstrukcji, niedopuszczalnym staje się więc pominięcie wymagań dotyczących zabezpieczenia antykorozyjnego w specyfikacji wyrobu i procesie jego wytwarzania.

Powyższe opracowanie odnosi się tylko do niektórych zagadnień związanych z problemem zabezpieczenia antykorozyjnego spawanych konstrukcji stalowych.

Elementem wspólnym dla wszystkich etapów procesu ochrony antykorozyjnej konstrukcji jest kompetentny i doświadczony personel. Niestety często spotykane jest pobieżne traktowanie tematu zabezpieczenia antykorozyjnego konstrukcji zarówno w wymaganiach stawianych przez zamawiających, jak również w projektach konstrukcji, a na wykonaniu i badaniach kończąc. Spotykane zapisy sugerują wprost, że ich autorom brak kompleksowej wiedzy w zakresie zabezpieczeń antykorozyjnych.

Ignoruje się również fakt, że tylko kompetentny personel, posiadający wiedzę i doświadczenie w zakresie antykorozji, jest w stanie zapewnić właściwe zaprojektowanie, wykonanie, nadzór i ocenę jakości wykonanych powłok. Temu podejściu sprzyja brak obligatoryjnych wymagań dla wytwórców konstrukcji, dotyczących posiadania kompetentnego personelu o określonym poziomie wykształcenia antykorozyjnego. Świadomość w tym zakresie pojawia się najczęściej dopiero w wyniku reklamacji klienta dotyczącej niewłaściwego wykonania powłok antykorozyjnych.

\section{Literatura}

[1] PN-EN ISO 8044:2002 Korozja metali i stopów. Podstawowe terminy i definicje.

[2] PN-EN 12944-1 $\div 8$ - Farby i lakiery - Ochrona przed korozją konstrukcji stalowych za pomocą ochronnych systemów malarskich. Części 1 do 8.

[3] PN-EN 1090-1,-2:2012 Wykonanie konstrukcji stalowych i aluminiowych.

[4] NORSOK M501:2012 Przygotowanie powierzchni i powłoki ochronne

[5] Zalecenia do wykonywania i odbioru antykorozyjnych zabezpieczeń konstrukcji stalowych drogowych obiektów mostowych. Załącznik do zarządzenia nr 15 Generalnego Dyrektora Dróg Krajowych i Autostrad z dnia 8.03.2006

[6] Tauron - Wytyczne $\mathrm{nr}$ 2/2/B/2012 w sprawie standaryzacji wymagań technicznych dla zabezpieczeń antykorozyjnych napowietrznych elektroenergetycznych konstrukcji stalowych. Załącznik nr 3 do zarządzenia nr 7/2012. Kraków 01. 2012

[7] Specyfikacje techniczne PO-TE-3-P. Wymagania Techniczne PSE-Operator S.A. dotyczące zabezpieczeń antykorozyjnych konstrukcji stalowych i stalowych ocynkowanych. Warszawa 06.2008

[8] PN-EN ISO 14713-1-2:2010 Powłoki cynkowe - Wytyczne i zalecenia dotyczące ochrony przed korozją konstrukcji ze stopów żelaza. Części 1, 2.

[9] PN-EN ISO 8501-1:2008 Przygotowanie podłoży stalowych przed nakładaniem farb i podobnych produktów - Wzrokowa ocena czystości powierzchni - Część 1: Stopnie skorodowania i stopnie przygotowania niezabezpieczonych podłoży stalowych oraz podłoży stalowych po całkowitym usunięciu wcześniej nałożonych powłok.
[10] PN-EN ISO 8501-3:2008 Przygotowanie podłoży stalowych przed nakładaniem farb i podobnych produktów - Wzrokowa ocena czystości powierzchni - Część 3: Stopnie przygotowania spoin, krawędzi i innych obszarów z wadami powierzchni.

[11] PN-EN ISO 8503-2:2012 Przygotowanie podłoży stalowych przed nakładaniem farb i podobnych produktów. Charakterystyki chropowatości powierzchni podłoży stalowych po obróbce strumieniowo-ściernej. Część 2: Metoda stopniowania powierzchni stalowych po obróbce strumieniowościernej. Sposób postępowania z użyciem wzorca

[12] PN-EN ISO 8502-3,-6,-9 Przygotowanie podłoży stalowych przed nakładaniem farb i podobnych produktów. Badania służące do oceny czystości powierzchni. Część 3, 6 i 9.

[13] PN EN ISO 2808:2008 Farby i lakiery. Oznaczanie grubości powłoki

[14] PN EN ISO 19840:2009 Farby i lakiery. Ochrona przed korozją konstrukcji stalowych za pomocą ochronnych systemów malarskich. Pomiar i kryteria przyjęcia grubości suchych powłok na chropowatych powierzchniach.

[15] PN EN ISO 2409:2013 Farby i lakiery. Badanie metodą siatki nacięć.

[16] PN EN ISO 4624:2004 Farby i lakiery. Próba odrywania do oceny przyczepności.

[17] PN EN ISO 9001:2008 Systemy zarządzania jakością. Wymagania. 